\title{
製紙に関係したポリアクリルアミドの一研究
}

\section{京都工芸繊維大学 町田誠 之 \\ A Fundamental Study of Polyacrylamide with Regard to Paper Making}

\author{
Seishi Machida \\ Kyoto University of Industrial Arts and Textile Fibers.
}

\begin{abstract}
The investigations of polyacrylamide concerning the paper making have been summarized. The acrylamide has been polymerized by an inverse emulsion polymerization. The modification of polyacrylamide by condensation with acetaldehyde has been studied, and the flocculation ability of the modified polymer has been discussed. For the purpose of obtaining the cationic derivatives, acrylamide has been copolymerized with 2-methyl- $N$-vinylimidazole. $N$-Dimethyl aminoethyl polyacrylamide and polyacrylic hydrazide have also been prepared with the same intention by the polymer analogous substitution of polyacrylamide. The applications of those cationic polymers to the paper making as wet end additives have deen investigated. A complex polyelectrolyte has been prepared by combining the partia'ly hydrolyzed polyacrylamide with polyethyleneimine. The complex polymer has been found to serve as a good flocculation agent and a wet end additive. The graft copolymerizations of acrylamide onto cellulose and petroleum resine have been also mentioned.
\end{abstract}

\section{1.むえがき}

最近，紙をとりまく社会的な環境は激しく変動を続 けている。原料の欠乏, 公害の規制, 労働力の不足な ぞの厳しい条件のなかで, 品質の向上, 生産量の増加, コストの低下などの要求を満たす努力が行なわ机てい る。この線に沿って紙の製造に高分子化合物を利用す ることも漸く一般化されるよらになってきた。

いらまでもなく，紙はセルロース又はこれと類似の 短繊維を水に分散させて薄い層にすき上げることによ って製造される。この際，繊維又はフィブリル表面に 生成する水素結合と繊維間の機械的な絡み合によって その形態が保持され，性質が支配される。このような 紙の本質に基いて製法を合理化し，品質を改良する有 力な方法として合成高分子化合物の応用が行なわれ， いろいろな面で大きな效果が得られている。

紙が水を媒体として製造されるものであるふら，こ れに用いる高分子は水溶性のもの方最子便利である。 水溶性高分子が製綎工業に利用される直接の目的は, 主としていわゆる内部添加用樹脂 (Wet end additive）として，サイジング，乾燥紙力増強，湿潤紙力 増強，スライム抑制，ピッチコントロール，消泡，填 料定着, 揆水加工など各種に分かれる。このほか, 紙 の表面塗布や加工にも用いられる。その上，水溶性高
分子は廃水の浄化に有力に活用されている。 水溶性高分子のなかで，特にアクリルアミド系のポ リマーが最近多く利用さ机ている。これは，このもの が他の高分子に比較して有利な特徴をもっているから である。すなわち，原料が豊富で比較的容易に安価で 得られる。モノマーもポリマーる水溶性の固体で得ら れ，精製も取り扱いも容易である。比較的簡単に高分 子量のポリマーが得られる。ポリマーは高分子反応に よって多くの誘導体に変成することがでさる。モノマ 一は他のコモノマーと共重合して各種の共重合体が得 られる。他の高分子にグラフト共重合学行なって，有 用な化合物が合成できる。他のポリマーとブレンドし て各種の用途に利用できる。などの特色がある。

筆者の研究室では，ふなり以前からアクリルアミド 系ポリマーに関する研究を行なってきて，その成果は 製紙工業にも多く利用されている。これらの結果の一 部をここに要約して何らかのご参考に供したいと思ら。

\section{2. 重合法について}

アクリルアミドは，水溶液にてラジカル重合を行な いポリマーを与える。製品は多くの場合， 5 〜 20\%濃 度の水溶液のままとなっている。これはポリマーを固 体状に分離するのに多量の沈殿剂孛必要とするなどの 不便があるからである。高濃度で重合反応を行ならと 


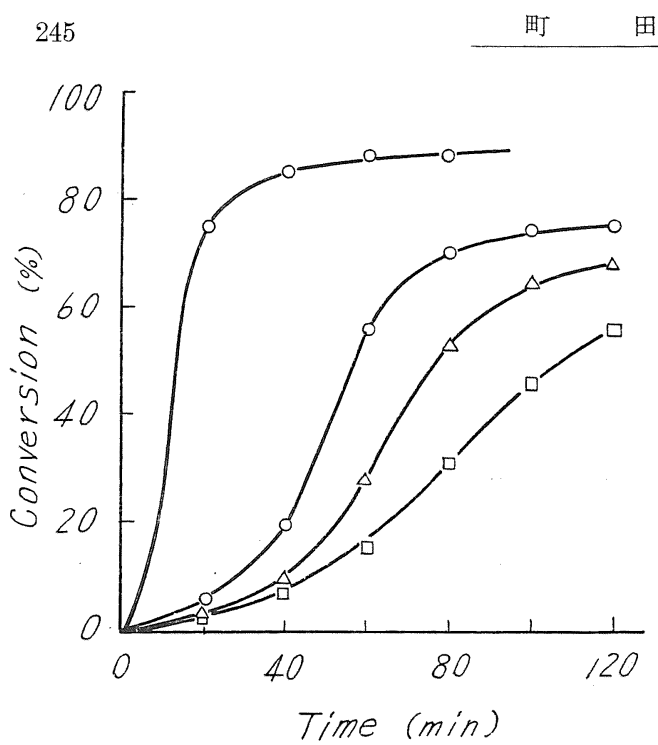

図 1 アクリルアミドの重合速度に対するイソプロピ ルアルコールの影響

Fig. 1 Effect of isopropyl alcohol on polymerization rate of acrylamide.
$\mathrm{O}[\mathrm{S}] /[\mathrm{M}]=0$;
() $[\mathrm{S}] /[\mathrm{M}]=0.121$;
$\triangle[\mathrm{S}] /[\mathrm{M}]=0.310$
$[\mathrm{S}] /[\mathrm{M}]=0.465$

溶液粘度が高くなり，重合熱を除くのが困難となり， 温度の調節がむずかしくなり，時にはゲル化を生ずる ことも起る。ポリマーを希薄溶液のますで工業製品と することは，運搬，貯蔵などからも非経済的である。 このために，ポリアクリルアミドを粉末製品とするこ とは望ましいことであるといわれている。

アクリルアミドの固相重合は多くの人によって研究 されているが，橋かけ反応を伴なって不溶性ポリマー を生じるなどの難点が多い。

噴霧重合は，モノマーを15４0\%の水溶液として重 合開始剤を加光て，150 450 $0^{\circ} \mathrm{C}$ の噴射ガス（空気な ぞ）と混合して短時間にスプレーして，直接に乾燥粉 末としてポリマーを得る方法である。しかし，この方 法はモノマーの損失が多く, ポリマーの重合度も低い。 水溶液重合をしたもの觉值接加熱する方法も, 不経 済である上に，高分子を分解劣化させる危険も西る。 また，高分子量のポリマー溶液は粘稠でとり报いが困 難となる。

水溶液からポリマーを沈殿分離させるときに，水々 混和せずにしかもポリマーも溶解しない有機溶郕（た と党ぱトルエン，キシレンなど）と，必要ならば適当 な乳化剤を加觉て油中水型エマルジョンとし，次に沈 殿剤（メタノール，アセトンなど）を加えてポリマー を分離する方法もある。しかし，操作が複雑である。

さらに，モノマーは可溶で, ポリマーは不溶の有機

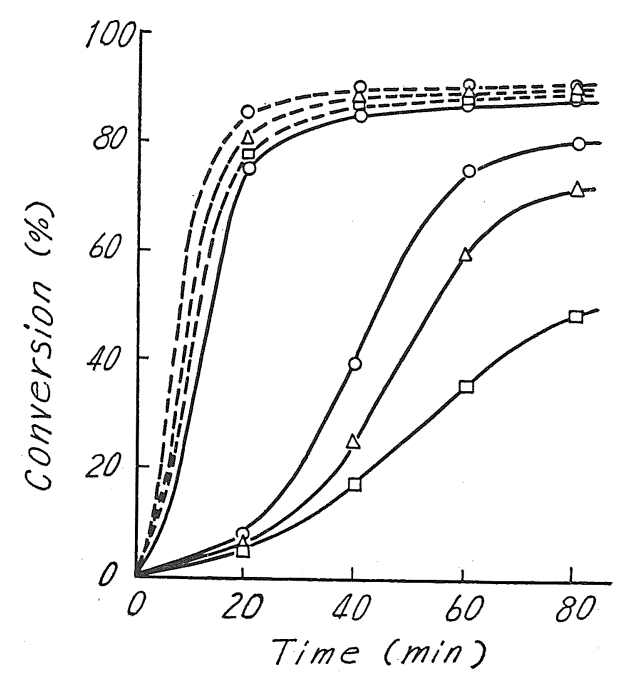

図 2 アクリルアミドの重合に対する $t$-ブチルアルニ ール及び $n$-ドデシルメルカプタンの影響

Fig. 2 Effect of tert-butyl alcohol and $n$ dodecyl mercaptane on polymerization of acrylamide.

-tert-butyl alcohol

…n-dodecyl mercaptane

$\begin{array}{ll} & {[\mathrm{S}] /[\mathrm{M}]=0 ;} \\ \triangle[\mathrm{S}] /[\mathrm{M}]=0.252 ; \square[\mathrm{S}] /[\mathrm{M}] /[\mathrm{M}]=0.126 \\ \triangle[\mathrm{S}]\end{array}$

溶剤（メタノール，アセトン，t-ブタノール，アセト ニトリルなど）中で重合させると，ポリマーが自然に 沈殿してくるので，これを分離する方法もある。けれ ぞも，これは多量の有機溶剂を必要とするほか，ポリ マーの分子量の高いものが得られない。

乳化重合を応用する方法もあるが，アクリルアミド が水に易溶であるために，いわゆる逆相乳化重合法と して, 油中水型ェマルジョンで重合させるのがよいと 考えられる。溶剤量，熱などには経済的である。

筆者ら ${ }^{1)}$ はアクリルアミドの50\%水溶液を乳化剂を 以て四塩化炭素中に分散させ, 過硫酸カリウム/亜硫 酸水素ナトリウム系レドックス開始剤を用いて, 比較 的低温 $\left(30^{\circ} \mathrm{C}\right)$ で重合させる方法を研究した。乳化剂 はソルビタンモノラウレートを用い, モノマー, 水, 四塩化炭素, 乳化剂を, それぞれ $1: 1: 8: 0.33$ の 割合で反応させると，かきまぜによって反応熱の調節 が容易で，副反応もなく円滑に重合が進行した。イソ プロピルアルコール， $t$-ブチルアルコール， $n$-ドデシ ルメルカプタンなどを連鎖移動剤として $0.1 \%$ 添加す ると簡単に重合度を調節することができる。これらの 実験結果は, 図1，2及び表1亿示される。顕幑鏡に よって観察すると, 重合率が一定になる頃から, 重合 したポリアクリルアミドの不定形の微小粒子が急激に 
凝集して，添济均一の直径約 $1.5 \sim 2 \mu$ の球状多孔質 の粒子となって得られることがみられる。ポリマーの 分離は少量のメタノール (反応液の約 2 倍量) で足り, 乾燥したポりマーは簡単に水に溶かすことができる。 この実験では分散媒に四塩化炭素を用いたので，この 物自身が連鎖移動剤として作用することもあって，ポ リマーの重合度を十分高くするには不適当である。他 の適当な有機溶剤を用いるための研究が必要であるう。 な括，逆に重合度の低いポリアクリルアミドを得る 場合には，テロメル化を行なうとよい。筆者ら2)はア クリルアミドを 5 倍量のブチルアルデヒドを溶解して 過酸化ベンゾイルを開始剤として重合させ，重合度17 〜40のポリマー（この場合はテロマーといら汪うが適 当である）を得た。この重合度は，開始剤の量などに よってある程度調節できる。この物は分子の末端にカ ルボニル基（ケトン基）をもっているので，この反応 性を利用して各種の用途が考兄られ，今後の研究に期 待している。

Table 1 Relation of molecular weight of polyacrylamide and polymerization time in the presense of isopropyl alcohol $([\mathrm{S}] /[\mathrm{M}]=0.465)$

\begin{tabular}{|c|c|c|c|}
\hline $\begin{array}{c}\text { Polymerization } \\
\text { time (hr) }\end{array}$ & $\begin{array}{c}\text { Intrinsic } \\
\text { viscosity } \\
{[\eta]}\end{array}$ & $\begin{array}{c}\text { Molecular } \\
\text { weight }\end{array}$ & $\begin{array}{c}\text { Degree of } \\
\text { polymeri- } \\
\text { zation }\end{array}$ \\
\hline 1 & 2.667 & 692,000 & 9,730 \\
2 & 2.638 & 680,000 & 7,560 \\
3 & 2.659 & 689,000 & 9,690 \\
4 & 2.592 & 663,090 & 9,320 \\
\hline
\end{tabular}

\section{3. 変成について}

ポリアクリルアミドはノニオン性の高分子であるが，

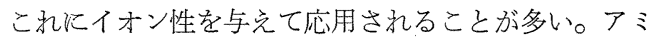
ド基は部分的に加水分解しやすく，アニオン性となる。 アニオン性ポリアクリルアミドを製紙に利用する場合 飞，その分子量やカルボキシル基含有量が添加効果に 与光る影響については古く W.F. Linke ${ }^{3)}$ の研究が ある。紙力増強剂としては, 分子量が 50 万, 加水分 解度 $10 \%$ 程度のものがよく, 白水凝集剤としては, 分子量が更汇高く, 加水分解度は $3 \sim 7 \%$ ののがよ いといら。N.T. Woodbery ${ }^{4)}$ が用途範囲を示した図 3はよく引用される。使用目的に応じて, 分子量や加 水分解度を調節する必要がある。ポリアリリルアミド を凝集剤として用いる場合には．たと党ば，A.S. Michaels ら $5^{5)}$ は重合度以高い添ぞ良く, 加水分解度は 28〜35\%がよいと述べている。これ関しては異論も

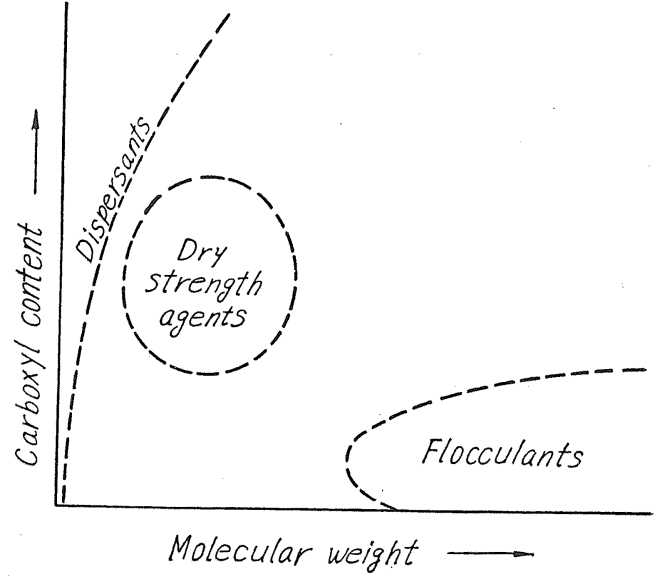

図 3 アクリルアミド系ポリマーの応用範囲

Fig. 3 Applications of acrylamide-based polymers

あるが，使用条件たと壳ば懸濁物の種類や添加量など によって変るのは当然である。

凝集作用は一般に粒子間の橋かけ機構によってよく

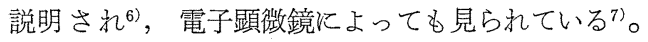
それでポリマーが水中で大きいひろがりを持つ注ど効 果的であることが理解される。適当な加水分解度によ ってポリマー鎖にイオン性基が導入されると，分子内 でイオン性基間に反発力が作用して分子が伸びた形に なる。加水分解が過度になると，アニオン性が強くな りすぎて懸濁粒子（多くの場合にその表面は負に带電 している）との反発を生じて，凝集能が低下すると考 完ら机る。

筆者ら8) はポリアクリルアミドに高分子反応を行な って適当な原子団を導入乙, 分子の屈曲性を制限寸れ ば水中で系まり状になることなく，大きなひろがりを 保ち，従って良好な凝集性を示すであうらと考光た。 実験では平均重合度約 1 万のポリアクリルアミドを用 いて，これにアセトアルデヒドを反応させた。

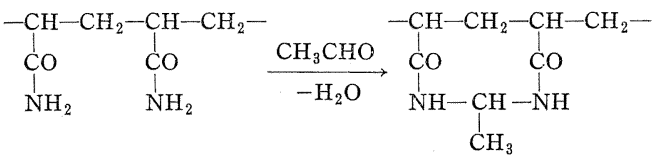

反応は溶液の $\mathrm{pH}$ 亿強く影響され; 酸性ではゲル化 を起しやすく, 水溶性誘導体の得られる $\mathrm{pH}$ の範囲は $2.6 \sim 3.3$, 反応温度は約 $60^{\circ} \mathrm{C}$ であった。この条件下 では，pH 值の低いほど，温度が高いほぞ，そしてア セトアルデヒド添加量が多い汪ぞ縮合率が高い。縮合 率が約 $70 \%$ をでは水溶性誘導体が得られ，それ以上で は不溶性となった。縮合率が高いほど固有粘度が高く なるのは表 2 亿示す通りである。この変成ポリアクリ 
Table 2 Intrinsic viscosity of acetaldehydecondensate of polyacrylamide

\begin{tabular}{|c|c|}
\hline $\begin{array}{c}\text { Condensation degree } \\
(\%)\end{array}$ & $\begin{array}{c}\text { Intrinsic viscosity } \\
(\mathrm{dl} / \mathrm{g})\end{array}$ \\
\hline 0 & 0.098 \\
5.6 & 0.165 \\
26.4 & 0.174 \\
55.6 & 0.179 \\
72.4 & - \\
\hline
\end{tabular}

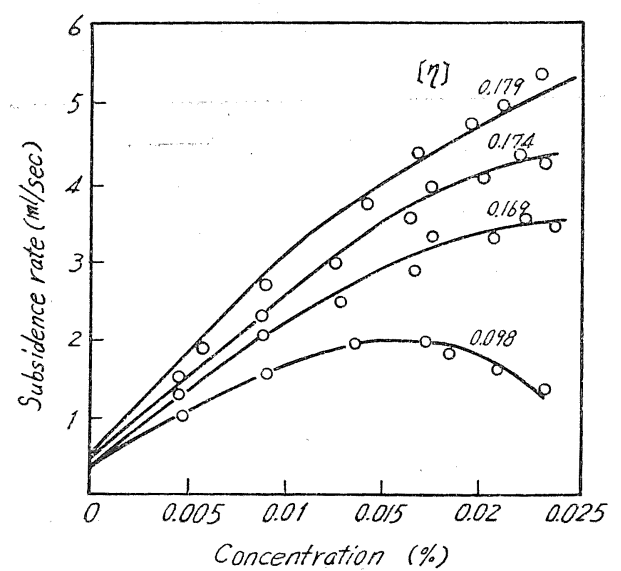

図 4 アセトアルデビ縮合ポリアクリルアミドによる カオリン分散液の㠜集

Fig. 4 Flocculation of kaolin dispersion with acetaldehyde-condensate of polyacrylamide

ルアミドを用いてカオリン分散液の凝集を実験した結 果は, 図4に示す通りである。予想通り良好な凝集作 用がみられ，その效果は固有粘度の高い子のほど，す なわち，変成度の高いもの漂ど蹎著で，乙かも，一旦 凝集した沈殿が再分散することがみられないという特 徽が認められで。

このように変成されたポリアクリルアミドの場合, あるいは加水分解された場合に，分子鎖に導入される イオン性基やかさ高い原子団の含有量とともに当然そ の分子鎖中での分布状態も考慮すべきもので㐫らら。 これらに関しての研究はまだ見出されていない。カル ボキシル基の導入については加水分解の方法艺調べる のも一法であるぶ゙，また，他のカルボキシル基をもっ たモノマーとの共重合物について比皎する方法も考光 られる。

筆者ら ${ }^{9)}$ はアクリルアミドにマレイン酸又はフマル 酸を共重合させることを研究したが，生成する共重合 体のミクロ構造などについて検討するには到っていな い。ただ，この研究から， $\alpha, \beta$-置換アクリル酸のシ
ス，トランスの立体異性体関して興味ある発展がみ られた ${ }^{10)}$ 。

水溶性高分子の凝集作用は，V.K. La Mer $ら^{11)}$ の 考えによると粒子の分散状態に到るまでの一種のバイ パスであるという。つまり，粒子の表面に少量の高分 子が吸着した場合には，橋かけ結合による凝集を起す が，多量の高分子が粒子表面を覆うと，逆に粒子の分 散を助子ることになるという。この考光は，筆者ら ${ }^{12)}$ がポリアクリル酸メチル部分加水分解物を用いてパル プ繊維の分散に関して行なった研究の結果からも支持 される。このことから当然, 多量のポリアクルアミド を添加すれば，これは分散剤として作用し，たと壳ば 和紙抄造のネリ剂として利用できる途が開かれる。

\section{4. 共重合について}

抄紙は水を媒体として行なわれるが，一般に水中に 分散している粒子の表面は負に帯電してる。それで従 来は，サイズや媜料の定着などには硫酸バンドなどの 水中でカチオン性の錯体を生成する物質を利用してい る。しかし，紙の種類によっては硫酸バンドの使用が 制限される場合も㐫り，また，吸着や㠜集の效果を高 めるために，カチオン性の物質（たとえば陽性デンプ ンや尿素ホルマリン樹脂など）の応用が行なわれるこ とがある。

ポリアクリルアミドにカチオン性空持たす試みもこ

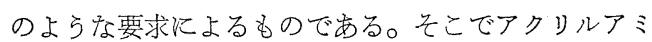
ドと他のカチオン性のビニルモノマーとを共重合させ ることがまず考えられる。カチオン性のビニル化合物 は一般に不安定で合成もむずかしく，例坊多くない。 筆者らは 2 -メチルーN-ビニルイミダゾールの重合性 及び重合体の性質を研究するなが ${ }^{14}$ )で，この物とアク リルアミドとの共重合体が優秀なサイズ定着作用と紙 力増強作用を示すことを見出した。15)<smiles>CCC(CC(C)C(N)=O)n1ccnc1C</smiles>

アセトンを溶媒としてアクリルアミド $\left(M_{1}\right)$ と 2メチルー $N$-ビニルイミダゾール $\left(M_{2}\right)$ を共重合させる と，後者の混合比が增すにつれて重合速度方低下する のがみられ，両者を等モルずつ採って $60^{\circ} \mathrm{C} て ゙ 5$ 時間 反応させた場合，重合率は $20.8 \%$ であ。単量体反応 性比として, $r_{1}=2.50, r_{2}=0.22$ 攵求められる。共重 合体は塩酸酸性溶液中でカチオン性高分子電解質の性 質を示す。 
この共重合体の $10 \%$ 溶液を塩酸で中和し，気乾パル プ試料に対して樹脂分換算 $0.1 \%$ に相当する量を加兄, サイズ剤を同じく $0.5 \%$ ，炭酸カルシウム媜料 $30 \%$ を 加壳てかきまき， TAPPI 式標準抄紙機にて抄造し， 湿紙はスチーム圧 $3 \mathrm{~kg}$ のドライヤー上で 3 分間乾燥 し，標準恒温恒湿室に 1 日間放置してから，紙料紙片 についてサイズ度をステキヒト法などで測定した。そ の結果は図５に示寸通りである。また，これと同様な 抄造法で，サイズ剂及び炭酸カルシウム填料を使用せ ずに，共重合体を゙樹脂分換算 $0.2 \%$ 量でけ添加して抄 造した試料紙について，その機械的強度定常法によっ て測定した結果表 3 を得た。ただし，表中の試料紙 No. 2-9は，共重合体を添加せずに抄紙したものであ る。

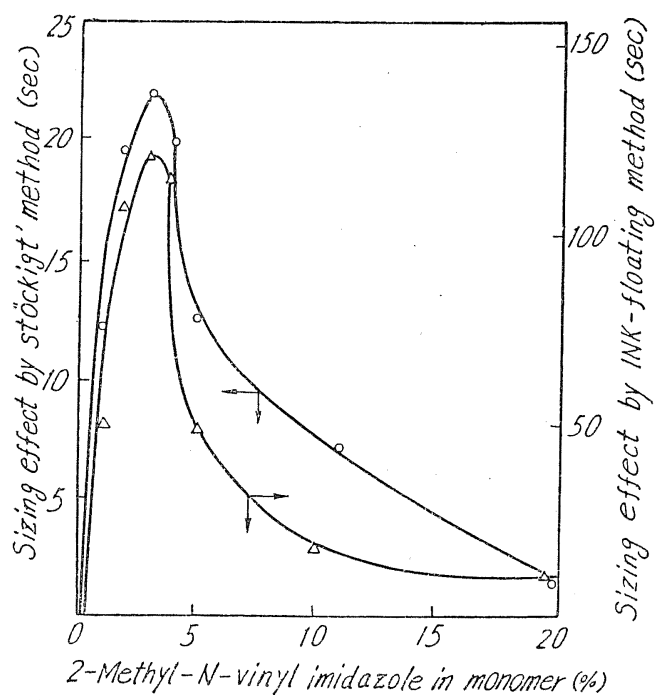

図 5 アクリルアミド/2-メチル-N-ビニルイミダゾー ル共重合体塩酸塩のサイズ効果

Fig. 5 Sizing effect of hydrochlorides of acrylamide copolymers with 2-methyl$N$-vinyl imidazole on paper.

Paper making: condition:

Pulp: L-BKP $33^{\circ}$ SR

Weight of paper: $60 \mathrm{~g} / \mathrm{m}^{2}$

Addition amount of copolymer : $0.1 \%$ to pulp

Size: Petroleum resinsize (0.5\% to pulp)

Filler: Calcium carbonate $(30 \%$ topulp)

これらの結果からみると, 合成の際に 2 -メチルーNビニルイミダゾールを1\%混合して共重合させたもの が，すでにサイズ定着と紙力増強の両作用を示し，そ の効果は 4〜 5\%の混入で最高を示し，10\%以上混入 したものは効果がか光って低下することがるかる。
Table 3 Effect of hydrochlorides of AA-MVI copolymers on properties of paper.

(Paper making conditions:-)

Pulp : L-BRP $33^{\circ} \mathrm{SR}$

Weight of paper: $60 \mathrm{~g} / \mathrm{m}^{2}$

Addition amount of copolymer: $0.2 \%$ to pulp

\begin{tabular}{|c|c|c|c|}
\hline $\begin{array}{c}\text { Sample } \\
\text { paper } \\
\text { No. }\end{array}$ & $\begin{array}{c}\text { MVI content } \\
\text { in monomer } \\
\text { mixture } \\
\text { (wt \%) }\end{array}$ & $\begin{array}{c}\text { Bursting } \\
\text { strength } \\
\left(\mathrm{kg} / \mathrm{cm}^{2}\right)\end{array}$ & $\begin{array}{c}\text { Tensile } \\
\text { strength } \\
\left(\mathrm{kg} / \mathrm{cm}^{2}\right)\end{array}$ \\
\hline $2-1$ & 0 & 1.15 & 3.21 \\
$2-2$ & 1 & 1.40 & 3.51 \\
$2-3$ & 2 & 1.45 & 3.58 \\
$2-4$ & 3 & 1.47 & 3.69 \\
$2-5$ & 4 & 1.51 & 3.75 \\
$2-6$ & 5 & 1.46 & 3.66 \\
$2-7$ & 10 & 1.45 & 3.66 \\
$2-8$ & 20 & 1.41 & 3.47 \\
$2-9$ & - & 1.04 & 2.94 \\
\hline
\end{tabular}

AA : Acrylamide

MVI : 2-Methyl-N-vinylimidazole

高分子を製紙用添加剤として応用する場合には，一 般に分子内の力チオン性基量と平均分子量とが添加効 果に直接に関係する因子となる。水中の紙料繊維の表 面を中和するには少量の塩基度で十分であるから，強 カチオン性の高分子は少量の添加で中和して等電点に 達する。けれども, 紙の乾燥強度を増すには到らない。 乾燥強度を増加するに必要な樹脂量を添加すれば，塩 基性が過剩になって定着効果が逆に減少する。それで カチオン性基の含有量には最適当があることになる。 また，高分子の分子量が高いものほ，分子内の多くの 点で繊維や填料を結合し，全体として大きなフロック を形成しやすい。結合い強力になる反面，大さな塊を つくることは紙質の均一性を害する危険を伴なら。そ れで分子量も場合に応じて調節する必要がある。この ような事情は W.L. Linke ${ }^{16)}$ も報告している。

筆者らはカチオン性の他の若干のモノマーの合成に ついて目下砳究中で，これらをアクリルアミドと共 琽合させると，各種のカチオン性ポリマーが得られる はずである。白水の浄化などに用いるカチオン性ポリ マーは，比較的低分子量のものでも相当の効果がるら れ，㠜集作用は有機質污濁物に対して殊に顕著に作用 乙清澄度が良い特街がみられる。今後の開発が期待さ れる。

\section{5. 䯩分子反応について}

前述のさらに，カチオン性モノマーは種類も少なく， 一般に不安定で合成导ずかしい。それで，アクリル 
アミドと共重合体をつくらせる研究も少ない。カチ才 ン性ポリアクリルアミドを得る一つの方法として，い わゆる等重合度反応 (Polymer analogous reaction) による方法はすでに 1943 年に A. M. Schiller ら ${ }^{17)}$ よって考光られている。

ポリアクリルアミドに次亜臭素酸アルカリを反応さ せて，いわゆる Hofmann 分解を行なうと，分子鎖 中にアミン基が生じる。けれども，これは複雑な副反 応を生じて単純な物質を得にくいことが知られている 18)。筆者 ${ }^{19)}$ は適当な条件を選ぶことにより，分子内に アミノ基とカルボキシル基とを適当な割合に有する高 分子両性電解質の得られることを見出した。

今一つの方法は，ポリアクリルアミドにホルムアル デヒドとアミンとを同時に反応させて，いわゆるマン ニッヒ反応を行ない，アミノメチル化誘導体に変光る 反応である。筆者ら ${ }^{20)}$ は，この反応を段階的に行ない 合理的な反応条件を研究した。

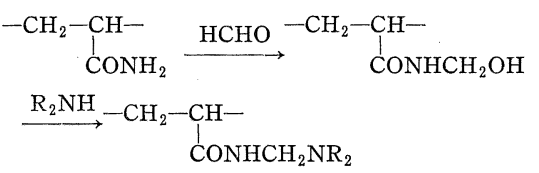

ポリアクリルアミドにホルムアルデヒドを反応させ てメチロール化する場合は，トリエタノールアミンを 触媒として弱アルカリ性で反応させるとよいことがわ かった。酸性での反応ではゲル化しやすい。 $N$-メチ ロールポリアクリルアミドにジメチルアミンを反応さ せて, ジメチルアミノメチル化物に変光る反応も弱ア ルカリ性で円滑に反応する。メチロールポリアクリル アミドに対して3倍モル量のジメチルアミンを加光， $70^{\circ} \mathrm{C}$ で 30 分間, $\mathrm{pH} 12$ で反応させると，全メチロー ル基の約 $75 \%$ がジメチルアミノ化される。これ以上の アルカリ性では加水分解棌よってカルボキシル基を副 生し，また，酸性では高分子間の橋かけなぞによって ゲル化する。中間にメチロール化物を取り出すことな く，ポリアクリルアミドにホルムアルデヒド，つついい てジメチルアミンを連続して反応させると都合よく反 応操作が行光ることを見出した。

この種のアミノ化ポリアクリルアミド誘導体は, す でに，沪水促進剤や白水浄化剤，あるいは填料定着剤 などに広く利用されている。

次筆者ら ${ }^{211}$ は, アクリルアミドにヒドラジンヒド ラートを反応させてポリアクリル酸ヒドラジドを合成 する研究を行なった。

$$
\underset{\mathrm{CONH}_{2}}{\stackrel{\mathrm{CH}}{\mathrm{C}}-\mathrm{CH}_{2}-} \stackrel{\mathrm{H}_{2} \mathrm{NNH}_{2} \cdot \mathrm{H}_{2} \mathrm{O}}{\longrightarrow} \underset{\mathrm{CONHNH}}{\longrightarrow}-\underset{\mathrm{CH}}{\longrightarrow}-\mathrm{CH}_{2}-
$$

Table 4 Size-retaining and paper-strengthening effects of polyacrylic hydrazide hydrochloride

Paper making conditions:-

Pulp : L-BKP $35^{\circ} \mathrm{SR}$; Weight of paper, $60 \mathrm{~g} / \mathrm{m}^{2}$

Size: Petroleum resin size $(1 \%$ to pulp) No filler

\begin{tabular}{|c|c|c|c|}
\hline $\begin{array}{c}\text { Addition } \\
\text { amount } \\
\text { (wt \% to } \\
\text { pulp) }\end{array}$ & \multicolumn{2}{|c|}{$\begin{array}{c}\text { Sizing effect } \\
\text { (sec) }\end{array}$} & $\begin{array}{c}\text { Bursting } \\
\text { strength } \\
\text { (kg/cm }{ }^{2} \text { ) }\end{array}$ \\
\cline { 2 - 3 } & $\begin{array}{c}\text { Stöckigt' } \\
\text { method }\end{array}$ & $\begin{array}{c}\text { Ink-floating } \\
\text { method }\end{array}$ & \\
\hline 0.1 & 0.9 & 1.9 & \\
0.2 & 35.3 & 708 & 2.67 \\
0.5 & 42.1 & 2,700 & 1.33 \\
0 & 0 & 0 & \\
\hline
\end{tabular}

Table 5 Size- and filler-retaining effects of polyacrylic hydrazide hydrochloride

Paper making conditions:-

Pulp: L-BKP $35^{\circ}$ SR; Weight of paper, $60 \mathrm{~g} / \mathrm{m}^{2}$

Size: Petroleum resin size $(1 \%$ to pulp)

Filler: Calcium carbonate (30\% to pulp)

\begin{tabular}{|c|c|c|c|}
\hline \multirow{2}{*}{$\begin{array}{c}\text { Addition } \\
\text { amount } \\
\text { (wt \% to } \\
\text { pulp) }\end{array}$} & \multicolumn{2}{|c|}{$\begin{array}{c}\text { Sizing effect } \\
\text { (sec) }\end{array}$} & \multirow{2}{*}{$\begin{array}{c}\text { Ash } \\
\text { (\%) }\end{array}$} \\
\cline { 2 - 3 } & $\begin{array}{c}\text { Stöckigt' } \\
\text { method }\end{array}$ & $\begin{array}{c}\text { Ink-floating } \\
\text { method }\end{array}$ & \\
\hline 0.25 & 50.2 & 414 & \\
0.50 & 54.8 & 3,600 & 11.6 \\
0 & 0 & 0 & 8.4 \\
\hline
\end{tabular}

ポリアクリルアミドに対して 10 倍量のヒドラジン ヒドラートを50〜 $55^{\circ} \mathrm{C}$ で反応させると，約 6 時間で 最高約 $85 \%$ のヒドラジド化が行なわれる。これ以上 の強い条件では副反応圭生じやすい。実際製紙の内 添剤に用いるにはヒドラジド化度は約 $10 \%$ で十分の効 果が現われる。

ポリアクリル酸ヒドラジドは，水によく溶けて高分 子電解質の挙動を示し, ヒドラジド化度の高いものほ ぞ粘度が高い。そして，塩酸溶液中でカチオン性を示 し，優れたサイズ定着及び紙力増強作用を示すことが 発見された。一例として石油樹脂サイズの定着剤とし て使用した実験結果を表 4 亿，また，炭酸カルシウム 媜料を定着する実験を行なった結果を表 5亿示す。ま た, 紙力増強作用も強く, 攵の効果ははアルファデン プン，アニオン化ポリアクリルアミド，カチオンデン プンなどよりも遙が高いことが見出された。 


\section{6. ポリマーブレンドについて}

陽性高分子としてポリェチレンイミンについて，以

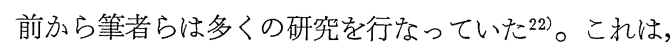
単量体の取扱いが不便（毒性，爆発性など）である流 か, 線状で高重合度のものが得難いなどの欠点もあっ た。そこで，この物とポリアクリルアミド（あるいは その部分加水分解物）とブレンドして一種の複合体と して利用する方法を研究した ${ }^{23)} 。$

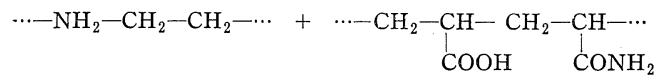

$$
\begin{aligned}
& \cdots \mathrm{CH}_{2}-\mathrm{CH}-\mathrm{CH}_{2}-\mathrm{CH}-\cdots \\
& \text {...- }-\mathrm{CH}_{2}-\mathrm{CH}_{2}-\mathrm{NH}_{2} \cdot \mathrm{OOC} \quad \mathrm{CONH}_{2}
\end{aligned}
$$

Table 6 Influence of polyethyleneiminepartially hydrolyzed polyacrylamide complex polyelectrolyte upon some

\begin{tabular}{|c|c|c|c|c|c|}
\hline \multirow{2}{*}{$\begin{array}{c}\text { Expri- } \\
\text { ment } \\
\text { No. }\end{array}$} & \multicolumn{2}{|c|}{$\begin{array}{l}\text { Composition of } \\
\text { flocculationg } \\
\text { agent }\end{array}$} & \multirow{2}{*}{$\begin{array}{c}\text { Retai- } \\
\text { ning } \\
\text { of filling } \\
\text { materials } \\
(\%)\end{array}$} & \multirow{2}{*}{$\begin{array}{l}\text { Stöck- } \\
\text { igt's } \\
\text { sizing } \\
\text { degree } \\
\text { (sec.) }\end{array}$} & \multirow[b]{2}{*}{$\begin{array}{l}\text { Bursting } \\
\text { strength } \\
\left(\mathrm{kg} / \mathrm{cm}^{2}\right)\end{array}$} \\
\hline & \begin{tabular}{|c|}
$5 \%$ Hydro \\
lyzed \\
poly \\
acryl- \\
amide \\
$(\%)$ \\
\end{tabular} & $\begin{array}{c}\text { Poly- } \\
\text { ethylene- } \\
\text { imine } \\
(\%)\end{array}$ & & & \\
\hline $5-1$ & 0 & 0 & 36.6 & 19.5 & 1.97 \\
\hline $5-2$ & 2 & 0 & 38.8 & 21.6 & 2.05 \\
\hline $5-3$ & 0 & 2 & 45.6 & 18.5 & 2.35 \\
\hline $5-4$ & 0.6 & 1.4 & 56.1 & 25.8 & 2.65 \\
\hline
\end{tabular}
properties of paper

Table 7 Elocculation of clay by polyethyleneimine and $5 \%$ hydrolyzed polyacrylamide

\begin{tabular}{|c|c|c|c|c|}
\hline $\begin{array}{c}\text { Experi- } \\
\text { ment } \\
\text { No. }\end{array}$ & $\begin{array}{c}0.1 \% \text { Solution } \\
\text { of } \\
\text { of hydro- } \\
\text { lyzed } \\
\text { polyacryl- } \\
\text { amide } \\
\text { (cc) }\end{array}$ & $\begin{array}{c}0.1 \% \text { Solution } \\
\text { of } \\
\text { ofyethyl- } \\
\text { eneimine }\end{array}$ & \multicolumn{2}{|c|}{$\begin{array}{c}\text { Supernatant } \\
\text { solution }\end{array}$} \\
\cline { 4 - 6 } (cc) & $\begin{array}{c}\text { Volume } \\
\text { (cc) }\end{array}$ & $\begin{array}{c}\text { Trans- } \\
\text { parency }\end{array}$ \\
\hline $1-1$ & 0 & 0 & 0 & - \\
$1-2$ & 1.0 & 0 & 0 & - \\
$1-3$ & 3.0 & 0 & 40 & $\triangle$ \\
$1-4$ & 5.0 & 0 & 50 & $\triangle$ \\
$1-5$ & 10.0 & 0 & 45 & $\triangle$ \\
$1-6$ & 0 & 0.5 & 0 & - \\
$1-7$ & 0 & 2.0 & 8 & $\triangle$ \\
$1-8$ & 0 & 5.0 & 0 & - \\
$1-9$ & 4.5 & 0.5 & 40 & $\bigcirc$ \\
$1-10$ & 4.0 & 1.0 & 50 & $\bigcirc$ \\
$1-11$ & 1.0 & 4.0 & 40 & $\bigcirc$ \\
\hline
\end{tabular}

clear; $\triangle$ turbid
この複合体は, 内部にカチオン性のイミノ基とアニ オン性のカルボキシル基をもつ一種の両性電解質と考 えられる。このイオン性は両成分の結合比, 重合度, 及びポリアクリルアミドの加水分解度や水溶液の水素 イオン濃度によって影響を受けるので，これらの因子 で調節することができる。両イオン性のバランスの取 れた所では白濁を生じるが，酸又はアルカリを添加す るか，加熱すれば透明になる。

この複合体は工業的に利用するときは，それぞれの 成分を単独に使用するよりも応用範囲が遥かに広く， 作用効果も高い。成分のポリアクリルアミドは, 実際 には $2 \sim 10 \%$ の加水分解度のものが良く，これに対し てポリエチレンイミンの混合率は95：5から 20：80 の範囲が適当である。これを紙料に添加すると, サイ ズ効果や紙力増強効果が非常に明白に現われる。一例 として, パルプ (LBKP; NBKP の等量混合物, S R $34^{\circ}$ ) にロジン系サイズ $2 \%$ 及びこの複合体を $0.5 \%$ ， そして硫酸バンド $2 \%$ を添加した紙の性質は表 6 のよ らな結果を示す。また，白水浄化作用を示す実験とし て, 製紙用クレーの $5 \%$ 懸濁液又は微細パルプ(LKP, $\mathrm{S} \mathrm{R} 86^{\circ}$ ) の $0.2 \%$ 懸濁液に，ポリアクリルアミドの 5 \%加水分解物及びポリエチレンイミンのそれぞれ 0.1 \%溶液を加えて凝集作用を観察した結果を，それぞれ 表 7 及び表 8 飞示す。

この複合体の特徵は, 添加効果が紙料液の $\mathrm{pH}$ のあ らゆる範囲で現われ, 硫酸バンドの使用の有無に関係 せずに効果を示すことである。硫酸バンドの存在下で は，従来のアニオン性高分子と同様の機構で作用し，

Table 8 Flocculation of fine pulp fibers (LKP $86^{\circ} \mathrm{SR}$ ) by polyethyleneimine and $5 \%$ hydrolyzed polyacrylamide

\begin{tabular}{|c|c|c|c|c|}
\hline $\begin{array}{c}\text { Experi- } \\
\text { ment }\end{array}$ & $\begin{array}{c}0.1 \% \text { Solution } \\
\text { of } 5 \% \\
\text { hydrolyzed } \\
\text { polyacryl- } \\
\text { amide } \\
\text { (cc) }\end{array}$ & $\begin{array}{c}0.1 \% \text { Solution } \\
\text { of polyethyl- } \\
\text { eneimine } \\
\text { (cc) }\end{array}$ & \multicolumn{2}{|c|}{$\begin{array}{c}\text { Supernatant } \\
\text { solution }\end{array}$} \\
\cline { 3 - 5 } $2-1$ & 0 & 0 & 0 & - \\
$2-2$ & 1.0 & 0 & 0 & - \\
Volume & $\begin{array}{c}\text { Trans- } \\
\text { parency }\end{array}$ \\
$2-3$ & 5.0 & 0 & 5 & $\triangle$ \\
$2-4$ & 10.0 & 0 & 0 & - \\
$2-5$ & 0 & 1.0 & 5 & $\triangle$ \\
$2-6$ & 0 & 5.0 & 10 & $\triangle$ \\
$2-7$ & 0 & 10.0 & 8 & $\triangle$ \\
$2-8$ & 4.5 & 0.5 & 45 & $\bigcirc$ \\
$2-9$ & 4.0 & 1.0 & 52 & $\bigcirc$ \\
$2-10$ & 1.0 & 4.0 & 46 & $\bigcirc$ \\
\hline
\end{tabular}


また硫酸バンドのない場合には，カチオン性高分子と して繊維に直接に定着作用を示す。それで，たとえば 炭酸カルシウムを填料とする紙の抄造や，トロロアオ イなどのネリ剂を使用する和紙の抄造，あるいは染料 を用いる染紙の抄造など，硫酸バンドの使用が不可能 か又は，それが制限される場合にも有効に使用できる 便利さがある。

ポリアクリルアミドに対して，このよらな他のポリ マーをブレンドして相乗的な作用を発揮させる方法も， 今後に大いに研究すべき分野であると考觉られる。

\section{7. グラフト共重合について}

筆者ら ${ }^{24)}$ は以前に，セルロースにアクリルアミドを グラフト共重合させる方法を研究した。その後，この 種のグラフトセルロースを紙料として抄紙する研究は， 多くの人によって行なわれて和り，興味ある発展が期 待される。

筆者ら ${ }^{25)}$ は，さらにグラフト共重合の基礎的な資料 を得るために，開始剤にセリウムイオンを利用し，セ ルロースにミクロクリスタリンセルロースを用いてア クリルアミドのグラフト重合を動力学的に研究した。 そして，得られたグラフト共重合体について，そのグ ラフト鎖の数と長さとが，その凝集沈降速度にどのよ らな影響を持つかを調べた ${ }^{26)}$ これによって，セルロ 一ス纎維がポリアクリルアミドによって凝集する機構 が明白になり，この種のグラフト共重合体の工業的応 用の進展に指針孞得られた。

アクリルアミドをセルロース以外のものにグラフト 共重合ざせことも考光られ，筆者ら ${ }^{27}$ は石油樹脂に ついて研究している。石油樹脂の分子にラジカル活性 点を与觉るためには，ジアゾニゥム塩にして分解する 方法やオゾン分解法などが試みられた。水溶性のグラ フト共重合体が得られるが，このものの利用について は今後の研究になたなければならない。

\section{8. 西とがき}

アクリルアミドはモノマーもポリマーも水溶性で無 色無臭であることは非常な特徵である。取扱いも，重 合も容易で，ポリマーは各種の誘導体变成できる。 製紙工業以じめ各方面に一層広く利用されるであるう から，これの基礎的な研究もさらに必要で岁ると思京 机る。

1) 町田，田中，䋖学誌，21，536 (1965)
2) 町田, 西尾, 有合化, 23, 596 (1965)

3) W.F. Linke, Tappi., 45, 326 (1962)

4) N. T. Woodbery, Tappi., 44, 156 A (1961)

5 ) A.S. Michaels, Ind. Eng. Chem., 46, 1485 (1954); A.S. Michaels, O. Morelos, ibid., 47, 1801 (1955)

6 ) W.E. Walles, J. Colloid Indterface Sci., 27, 797 (1968)

7) H.E. Ries, B.L. Meyers, J. Appl. Polymer Sci., 65, 2023 (1971)

8 ) 町田, 芦田, 有合化，27，764 (1969)

9 ) 町田, 成田, 有合化, 24，467 (1966)

10) K. Matsuo, S. Machida, J. Polymer Sci., A-1, 10, 187 (1972)

11) T.W. Healy, V. K. La Mer, J. Colloid Sci., 19, 323 (1964)

12）町田, 吉野, 繊学誌, 18, 142, 981 (1962)

13）町田，コロイドと界面活性剤，1，283（1960）

14）町田，服部，有合化，25，324（1967)；町田，清 水，牧田，紙八゚技協誌，21，352（1967）; 町田， 渡辺，同上，22，253 (1968)； S. Machida, M. Araki, K. Matsuo, J. Appl. Polymer Sci., 12, 325 (1968) など

15) 町田, 斉藤, 繊学誌, 23, 301 (1967)

16) W.F. Linke, Tappi., 51, No. 11 (1968)

17) A.M. Schiller, T. J. Suen, Ind. Eng. Chem., 48, $2132(1956)$

18）杉浦，越智，谷，永井，工化，72，1926（1969） など

19）町田，片瀬，未公表

20）町田，西久保，田中，有合化，23，510（1965）

21）町田，荒木，袟原，紙，技協誌，21，401 (1967); S. Machida, Tappi., 52, 1734 (1969)

22）町田, 化学の領域，16，865（1962）；町田，染 色工業，9，632，690，756 (1961)；10，18，75 152，203（1962）；町田，内野，町田（潤，，加 門，堀，繊学誌，14，892（1958）；町田，吉井, 山田，紙パ技協誌，19，389(1965)

23）町田，吉井，山田，紙パ技協誌，19，358（1965)

24）成田, 内野, 町田, 繊学誌, 19, 225 (1963)；20, 187 (1964)；成田，町田，高化，22，79 (1965)

25) 成田, 町田, 繊学誌, 27, 162 (1971)

26) S. Machida, H. Narita, T. Katsura, Angew Makromol, Chem., 20, 47 (1971)

27）町田，西岡，旅家；有合化，26，595（1968）； 町田，荒木，辰巳，紙パ技協誌，22，575（1968） 